\title{
Federico Regaldo* Who is Going to Pay for Causing Pandemics?
}

https://doi.org/10.1515/gj-2020-0049

Published online November 6, 2020

\begin{abstract}
In the modern, globalized, world, millions of laws and statutes are applicable to humankind, in order to curb and regulate the activity of every individual. Within the last decades, sanctions multiplied and aggravated, but who is going to pay for having caused a catastrophic pandemic? Actually, it seems that the answer is: "nobody". However, the article gives some suggestion, by applying new "eco-tort" and civil liability principles to this new and unprecedented crisis. Furthermore, it gives some urgent public policy guidelines to minimize the risk of new pandemics. It also advocates a new world order, based on the promotion of anti-speciesism, non-violence, environmental protection and fair sharing of natural resources, while rejecting the free market theories: it seems the best way for finally overcoming the crisis and preventing new ones.
\end{abstract}

Keywords: pandemics, farming, liability, meat, anti-speciesism

\section{Introduction}

In the modern, globalized world, millions of laws and statutes are applicable to humankind, in order to curb and regulate the activity of every individual. Most part of these laws and statutes carry with them a sanction, alongside the principle of public liability, according to which the injured party may sue and seek compensation from the person responsible for the injury.

Within the last decades, sanctions multiplied and aggravated, especially in cases in which it is difficult to identify a specific injured person and the governmental bodies consider that infringing the prescribed behavior creates a risk or damage for the entire community.

Therefore, despite the technological improvement of motor vehicles, which renders them much safer than before, speed limits have been constantly reduced and prohibitions are extensively enforced and sanctioned: in many European countries, speeding of only few kilometers per hour may cost a criminal proceeding, in case of lack of prompt payment of the fine.

*Corresponding author: Federico Regaldo, Euralex Group, Brussels, Belgium, E-mail: regaldo@euralexgroup.eu 
Remaining in Europe, the recent General Data Protection Regulation (GDPR) is now imposing draconian administrative fines, for violation of some of its provisions "up to 20,000,000 EUR, or in the case of an undertaking, up to 4\% of the total worldwide annual turnover of the preceding financial year, whichever is higher". 1

What is a sanction for causing a pandemic, taking million lives and provoking billion Euro of damages, if not putting at risk of collapse the entire word economy? None, so far.

This answer is astonishing: since a couple of millenniums, the old Roman law dictum: "cuius commoda et eius incommoda" (who gets the benefits should also bear the costs) $)^{2}$ is one of the fundamental principles of law and it is unbelievable that responsible of pandemics could escape from it.

This is especially true in the case of pandemics, since, as we will see, they are the exact result of somebody making huge profits, while putting others at great risk and "those who profit by exposing others to especially high risk will be using up more than their own share (of resources) if they are not held liable". ${ }^{3}$

Furthermore, as it will be shown, several elements for establishing the liability seem existing in most part of pandemics: in particular, evidence shall be given on the existence of:

1) The injuries;

2) The duty of care;

3) The responsible persons.

Unfortunately, this article does not offer any solution for practically seeking (and obtaining) compensation from the authors of this kind of catastrophic events, especially with reference to cross-border enforcement of favorable court decisions. Indeed, the idea that "the traditional ex post structure of individual rights protection can be of use" is just an "illusion". 4

Furthermore, it goes without saying that any legal system uses its own criteria for interpreting the three elements above and that liability assessment, as a matter

1 Art. 83, §5, of Regulation (EU) 2016/679 of the European Parliament and of the Council of 27 April 2016, on the protection of natural persons with regard to the processing of personal data and on the free movement of such data, and repealing Directive 95/46/EC (General Data Protection Regulation), in the Official Journal of the European Union, of 4 May 2016, L 119/1.

2 Mattei, U. and Quarta, A. 2018. The Turning Point in Private Law - Ecology, Technology and the Commons. Cheltenham: Edward Elgar Publishing, chap. 4.

3 Idem (Gordley 2006).

4 Idem. 
of fact, can vary extensively from one Country to another. E.g.: it seems that liability can be more easily established in one of the several States of the USA (like e.g. Florida and Massachusetts), where a mere foreseeability test is required, rather than in the others, where further elements are required.

At the same time, it seems even more difficult to establish the liability with the threefold test recently developed under English law. ${ }^{5}$

Nowadays, enormous damages are created by "a complex social relationship of production and marketing that involves both private and public decision makers" and a "simplistic model of culpability or strict liability" is no longer viable. $^{6}$

However, it is interesting to note, as it will be seen, that the three elements of the tort of negligence above may be found in several pandemics, although it will be for the local lawyers to explore the likelihood of success of lawsuits against the responsible persons on a case-by-case basis.

Therefore, this commentary aims to ascertain some facts and propose some principles, which should be followed, and measures, which should be urgently taken into account, once the current pandemic shall end, in order to prevent a new, and perhaps even more devastating, one.

This contribution wishes to be in line with what has been defined as a new "eco-tort law", focusing on the prevention of damages, rather than "reducing certain kinds of damages to dollars and cents", while very well on route towards an "ecological catastrophe". ${ }^{7}$

\section{The Injuries}

On this point, with reference to the current Covid-19 pandemic, it is sufficient to refer just few numbers.

At the time of writing (12 October 2020), the Covid-19 pandemic has infected more than 37 million people worldwide; 1,074,817 people died for causes related to SARS-CoV-2 virus. ${ }^{8}$

5 See Caparo Industries plc v Dickman ([1990] 2 AC 605), in which the House of Lords has made the liability subject to the following three conditions: not only the damage must be (i) a "reasonably foreseeable" result of the defendant's conduct, but also (ii) a relationship of "proximity" must exist between the defendant and the plaintiff and (iii) it must be "fair, just and reasonable" to impose liability.

6 Mattei, U. and Quarta, A., cit.

7 Idem.

8 WHO. 2020. Health Emergency Dashboard - WHO (COVID-19) Homepage. https://covid19.who. int/ (accessed October 12, 2020) 
Always at the time of writing, the economic loss caused by the Covid-19 pandemic is incalculable. According to the IMF, fiscal measures adopted by G-20 Countries only are generating costs in the region of USD 11 trillion. ${ }^{9}$

Furthermore, huge collateral damages shall probably remained unaccounted. E.g. the number of persons committing suicide, for the loss of their employment or their business; or affected by serious depression for being forced to stay at home; or affected by famine due to economic collapses within the poorest regions of the world; etc.

In any case, a precise cost assessment is extremely complicated. Some guidelines can be taken from the past earthquakes, ${ }^{10}$ but a pandemic in modern day is an unprecedented event with unprecedented costs. For our purposes, and it is quite likely that everyone shall share this view, costs of a pandemic are so high, surmounting any previous threshold reached so far and of a nearly unthinkable magnitude.

On the other hand, it must be noted that practically everyone can be damaged in pandemics, at least in economic terms. In Italy, the first lawsuits against the People Republic of China for aggravating the current pandemic have been brought, indeed, by a transporting company and by two local hotel-restaurants, both heavily affected, in economic terms, by the lockdown. ${ }^{11}$

\section{The Duty of Care: Is a Pandemic Foreseeable?}

Yes, it appears to be so.

This answer, as it will be seen, is largely based on pre-Covid-19 literature.

After the emerging of the current pandemic, a vast literature has developed, affirming everything and its contrary and therefore it is irrelevant from the point of view of an ex-ante foreseeability test.

9 Georgieva, K. 2020. The Next Phase of the Crisis: Further Action Needed for a Resilient Recovery. Washington: IMFBlog. https://blogs.imf.org/2020/07/15/the-next-phase-of-the-crisis-further-actionneeded-for-a-resilient-recovery/ (accessed October 19, 2020).

10 See Monti, A. 2011. "La gestione assicurativa e finanziaria del rischio terremoto in Cile: analisi giuridica del corrente assetto istituzionale e delle prospettive di riforma alla luce dell'esperienza in area OCSE”, in Diritto ed economia dell'assicurazione (4): 1397.

11 See the news on the two cases, given by the press: "Azienda di trasporti torinese fa causa alla Cina, denunciando 1.3 milioni di mancati guadagni”. May 20, 2020. Torinoggi.it. https://www. torinoggi.it/2020/05/20/leggi-notizia/argomenti/cronaca-11/articolo/azienda-di-trasporti-torin(e)sefa-causa-alla-cina-denunciando-13-milioni-di-mancati-guadagni.html (accessed October 19, 2020) and: "Le nostre attività in ginocchio per il Covid-19. Due albergatori canavesani denunciano la Cina". May 5, 2020. Canavese news.it. https://canavesenews.it/news/le-nostre-attivita-ginocchio-covid-19due-albergatori-canavesani-denunciano-la-cina/ (accessed October 19, 2020). 
On the other hand, it is amazing to note that some pre-Covid-19 books were already considering the likelihood of similar pandemics as extremely realistic, if not imminent.

The alternative is therefore the following: either these authors are novelists, active in the science-fiction area; or they were already reporting the views of experts, fully aware of some very dangerous human activity and concerned for its possible catastrophic outcomes. Tertium non datur.

In other words, for many years, there was a numerous bunch of individuals who were (or should have been) fully aware of the potential disastrous consequences of certain activities, but they did not care about both the people's health and the general long-term devastating repercussions of such hazardous activities on the economic system.

The very dangerous activity at stake, as it will be seen, has a clear name: meat production. Outbreaks of potentially catastrophic pandemics have taken place across the world for many years and they were all connected to some form of exploitation of non-human animals or to the devastation of natural habitats.

Nevertheless, throughout the years, such exploitations and devastations not only continued unchanged, but expanded towards developing Countries.

If the current pandemic was not foreseeable for the common people, it certainly was (or it should have been) for the largest exploiters of non-human animals - e.g. in the USA, the largest part of the beef production market is controlled by few corporations ${ }^{12}$ - and it certainly was (or it should have been) for health authorities and regulators.

Unfortunately, it seems that:

(i) The largest exploiters of intensive farming and the promoters of deforestation were only concerned with making profit;

(ii) Health authorities and regulators were only concerned with non-disturbing, if not facilitating, those who were making profit.

In any case, it seems that all of the above subjects are completely disregarding their duty of care towards the others.

The duty of care can be defined as an obligation, imposed on a person, requiring the compliance with a standard of reasonable care, while performing any act that could foreseeably harm others.

12 Joy, M. 2010, 2011. Why We Love Dogs, Eat Pigs, and Wear Cows: An Introduction to Carnism, edited in Italian by Massaro, A and Sobbrio, P. 2012. Perché amiamo i cani, mangiamo i maiali e indossiamo le mucche. Un'introduzione al carnismo e un processo alla cultura della carne e alla sua industria. Casale Monferrato: Edizioni Sonda, 1430-1435, Kindle. 
It has longer been established, in certain jurisdictions, that the duty of care can be still found in situations where plaintiffs and defendants may be separated by vast distances of space and time. ${ }^{13}$

Indeed, nowadays pandemics are transported by planes, in few hours, from a continent to another and a strict proximity requirement would be completely out of date.

The principle of a general duty of care, that runs to all who could be foreseeably affected by someone's conduct, dates back at least to the early twentieth century, when a US Court has clearly established it, in a product liability case. ${ }^{14}$

As anticipated, the current test for assessing the existence of a general duty of care varies from a legal system to another: from a mere foreseeability test, adopted in some of the US States; to the triple test adopted in England and Wales; ${ }^{15}$ to the multi-factor test adopted in some other US States.

However, the pandemic is a disease characterized by its quick spreading to the world at large. It would be completely meaningless to limit the duty of care through "proximity" or other tests. Should the responsible persons owe a duty of care only to the first victim, to the first million victims or to the world at large?

It is clear that such a limitation would make no sense. A pandemic is such a devastating phenomenon that, if not for the reason to put pressure to avoid it as much as possible, duty of care should find no limitation but the foreseeability.

Leaving aside, for a while, the common law tradition, a very good model can be found in Article 2050 of the Italian Civil Code (enacted in 1942 and still into force), which, under the heading of: "Liability in conducting dangerous activities", states:

"Anyone who causes an injury to others while conducting a dangerous activity, as such or due to the means deployed, is liable, unless he gives evidence to have adopted all the suitable measures for avoiding the injury". ${ }^{16}$

This provision differs from the one on general liability (provided at Article 2043) since it:

- Reverts the burden of proof: in case of performance of dangerous activities, it is not the injured person who must prove the existence of the duty of care and

13 See e.g. Terlinde v. Neely, 275 S.C. 395, 271 S.E.2d 768 (1980).

14 MacPherson v. Buick Motor Co., 217 N.Y. 382, 111 N.E. 1050 (1916). However, a different result could be reached by applying English Law.

15 See Caparo Industries PLC v Dickman, cit.

16 My translation. 
the breach of the duty of care; it is for the responsible person to prove that he has adopted all suitable measures for avoiding the injury; and

- Reinforces the standard of care: the responsible person shall not be acquainted if he proves to have adopted only the reasonable or standard measures for avoiding injuries. He must prove to have adopted all "suitable measures for avoiding the injuries”, according to the latest available techniques.

This Italian provision aims to supporting the technical progress, which is made, unfortunately, also of dangerous activities, curbing, at the same time, the free market trend, by imposing a reinforced duty of care on those making profits out of dangerous activities.

A rigorous application of this provision to current Covid-19 pandemic could give material results. Indeed, some authors ${ }^{17}$ rightly point out that provisions like the one at stake, promoting a so-called "strict liability" model, have no strong effect in preventing damage to the society and environment, but just make the risk taker internalizing a smaller share of the cost debited to the latter. However, in case of pandemics, costs are so high compared to profits, that, if strict liability would be applied, many risk takers would probably be discouraged from taking them.

As it will be seen, especially CAFOS (the acronym is used by experts to indicate intensive farming, named as "Confined Animal Feeding Operations") and Wet Markets ${ }^{18}$ are inherently dangerous activities for the causation of pandemics.

In case a specific CAFOS or Wet Market giving origin to an epidemic is identified (as it will be seen, this is true for several cases), for the injured person it will be sufficient to prove:

1) The injury - which it is not a difficult task; and

2) The fact that the responsible person failed to adopt all "suitable measures for avoiding the injuries", according to the latest available techniques: on this point, it is self-evident that:

17 Mattei, U. and Quarta, A., cit., chap. 4.

18 The term "Wet" refers to the fact that the blood of the non-human animals, slaughtered upon customer's purchase, soaks the market's floor. 
(i) Confining thousands of immuno-depressed animals in small cages, ${ }^{19}$ like in all CAFOS; or

(ii) Slaughtering all sort of animals in horrendous hygienic conditions, in front of customers, like in all Wet Markets;

although permitted by the applicable laws, does not amount to adopting all "suitable measures for avoiding the injuries" according to the latest available techniques. Indeed, it is quite clear that exploiters of CAFOS and Wet Markets have certainly adopted the latest available techniques for increasing their output and profits, but probably not for protecting public health.

Therefore, by easing the burden of proof of the injured and reinforcing the standard of care of the responsible, Art. 2050 of the Italian Civil Code could prove to be an important tool in asserting the liability for causing pandemics.

But let us go back to the common law elements of the tort of negligence; are pandemics foreseeable?

Also in this case, the answer appears to be an affirmative one.

Warning bells were sounding for many years. Paul Roberts, in 2008, was reporting of:

- $\quad$ A case taken place already in 2003, in the Netherlands, of an H7 virus, coming from poultry flocks, which had infected a hundred people and killed one;

- A case taken place in 2004, in an eggs' farm of the British Columbia's Fraser Valley, which went zoonotic and infected humans, although, "for reasons researchers still don't fully understand”, the outbreak never went fully zoonotic and did not become highly pathogenic to humans nor gain the ability to jump easily from human to human. ${ }^{20}$

19 "Larger population sizes and densities facilitate greater rates of transmission. Such crowded conditions depress immune response. High throughput, a part of any industrial production, provides a continually renewed supply of susceptibles, the fuel for the evolution of virulence. There are additional pressures on influenza virulence on such farms. As soon as industrial animals reach the right bulk they are killed. Resident influenza infections must reach their transmission threshold quickly in any given animal, before the chicken or duck or pig is sacrificed. The quicker viruses are produced, the greater the damage to the animal. Increasing age-specific mortality in industrial livestock should select for greater virulence. With innovations in production, the age at which chickens are processed has been reduced from sixty to forty days, increasing pressure on viruses to reach their transmission threshold-and virulence load-that much faster" (Wallace, R. 2016. Big Farms Make Big Flu: Dispatches on Influenza, Agribusiness, and the Nature of Science. New York: Monthly Review Press, 852-861, Kindle).

20 Roberts, P. 2008. The End of Food. Boston-New York: HMH Books, 176-177, Kindle. 
Later cases were involving other non-human animal farming industries: e.g. a swine flu outbreak was transmitted to the local population in south-eastern Mexico in $2009 .^{21}$

The problem looks always the same: free market forces push more and more for larger exploitations and cost reductions, completely disregarding the welfare of animals, both non-human and human.

Rob Wallace calls the swine farms as "porcinopolises", grown up "to the point that whole human communities are pushed off the land pigs now occupy". 22 The Author points out that although "H1N1 (2009) turned out to be less widespread and virulent than initially expected (...) globally as many as 579,000 people may have died from the virus and its complications appeared 15 times greater in incidence than initially projected by lab tests". ${ }^{23}$

It is worth citing exactly what Paul Roberts said, already many years ago, that it now looks prophetic for the population, but was certainly very well known by farmers, vets and health authorities:

"This is worth keeping in mind. Although the media have been filled with what-if flu scenarios, a reprise of the 1919 outbreak would far exceed anything Hollywood has imagined by several orders of magnitude. Based on the small-scale epidemics in Asia, and taking into account the ease with which illnesses are transmitted in modern cities and the utter inadequacy of our medical system, forecasts for a full-blown worldwide pandemic suggest that a high-path virus could kill as many as seventy million people. There would be trillions of dollars in economic damage as billions of workers stay away from work, and massive political instability as supplies of flu vaccines, antivirals, and even chlorine to purify municipal water systems are quickly exhausted, and governments buckle under the gruesome but essential chore of 'corpse management", ${ }^{24}$

\section{And even more:}

“Given the virus's talent for rapid mutation, and given the character of the modern poultry business, with its large flocks of densely concentrated, highly susceptible birds, many experts regard the prospect of a lethal human AI outbreak as a question of 'when', not 'if'. 'All it takes is a single mutation and you suddenly have a very pathogenic virus', Victoria Bowes, an avian pathologist with the BC ministry of agriculture and lands, told me. And on the modern chicken farm, says Bowes, "we provide them with barns full of virus incubators"”. 25

21 Tuckman, J. 2009. "Four-year-old could hold key in search for source of swine flu outbreak". April 29, 2009. The Guardian. http://www.theguardian.com/world/2009/apr/27/swine-flusearch-outbreak-source (accessed October 20, 2020).

22 Wallace, R., cit., 486, Kindle.

23 Idem, 726-731.

24 Roberts, P., cit., 176.

25 Idem, 177. 


\section{As a matter of fact:}

"Few activities are as worrying as the rapid expansion of meat production, particularly in the developing world. (...) Livestock and poultry farmers tended to build their operations near big cities. (...) In the context of avian flu, this rapid buildup of urban poultry production has two primary implications. First, the trend toward commercial poultry flocks that are closely confined and genetically uniform makes it far easier for the pathogen to generate and then be shed in massive quantities. Second, it has created millions of opportunities for bird-human mixing. (...) Nearly half of poultry production in China, Indonesia, Vietnam, and neighboring countries still occurs in backyard flocks and so-called small-enterprise operations of between thirty to a thousand birds. Unfortunately, these small-scale producers play a leading role in the colonization of avian flu. Moving frequently between farms and local markets, farmers and traders can easily transmit infection from flock to flock and market to market-often well before the birds show any visible signs of infection". ${ }^{26}$

And, last but not least, with reference to potential pandemics of avian flu:

“... The gravest fears center on China, where the disease started in 1996 and where efforts to halt its spread are most lacking". ${ }^{27}$

Strong warnings that the next pandemic strain would arise in southern China were already spoken out in $1995 .^{28}$

The link between viruses potentially triggering pandemics and non-human animal exploitation is a constant one:

"In late 2006 virologist Guan Yi and his colleagues at the University of Hong Kong reported on a previously uncharacterized H5N1 lineage they named "Fujian-like," after the putative Chinese province of origin. They ascribed the emergence of the strain as a viral evolutionary reaction to the government's campaign to vaccinate poultry. The virus appeared to evolve from underneath the vaccine coverage". ${ }^{29}$

“... Samples of highly pathogenic H5N1 were isolated by Chinese scientists from a 1996 outbreak on a goose farm in Guangdong”. ${ }^{30}$

What, for most part of the worldwide population, seemed to come out of the blue, for worldwide experts appears to be an everyday concern since long time. In particular, the relationship with China and influenza is described as "a long story":

"A variety of subtypes have been discovered emanating from southern China, Guangdong included, for decades. In the early 1980s, University of Hong Kong microbiologist Kennedy

26 Idem, 201-202.

27 Idem, 202.

28 Wallace, R., cit., 321.

29 Idem, 218. Findings of such virologist have been rejected by Chinese officials.

30 Idem, 250. 
Shortridge identified 46 of the 108 different possible combinations of hemagglutinin and neuraminidase subtypes circulating worldwide at that time in a single Hong Kong poultry factory. In WHO's own bulletin, Shortridge, writing in 1982, detailed the likely reasons southern China would serve as ground zero for the next influenza pandemic:

- Southern China hosts mass production of ducks on innumerable ponds, facilitating fecaloral transmission of multiple influenza subtypes.

- The greater mix of influenza serotypes in southern China increases the possibility the correct combination of gene segments would arise by genetic reassortment, selecting for a newly emergent human strain.

- Influenza circulates year-round there, surviving the inter-epidemic period by transmitting through the fecal-oral mode of infection.

- The proximity of human habitation in southern China provides an ideal interface across which a human-specific strain may emerge.

The conditions Shortridge outlined have since only intensified with China's liberalizing economy". 31

In the light of the above, the following conclusions on foreseeability can be drawn:

1) To anyone who is professionally engaged in an activity related to meat production the possibility of giving origin to a pandemic, through his activity, is (or should be) foreseeable. No one can deny the existence of the literature cited above and the world it described, in which pandemic risk was considered as imminent already many years ago;

2) For the same reasons, the likelihood that meat production is causing a pandemic is even more foreseeable to anyone who is engaged in such activity in southern China.

Therefore, if the professional activity of one or more of the persons engaged in meat production shall give rise to a pandemic - and therefore such persons shall be identified as "responsible persons" - they cannot claim that pandemic was not foreseeable.

However, we will see in the next chapter that, although sometimes it is less complicated to determine who is the responsible person, quite often such identification task remains a difficult one, for technical or even political reasons.

31 Idem, 302-316. 
This seems to be true also for the current pandemic, whose origins are still debatable.

\section{The Responsible Persons}

Paul Roberts, always in 2008, was already suggesting an important measure to prevent pandemics:

"What is needed is a strong public position by credible authorities-a position that lays out the huge external costs of a heavy meat diet and articulates the way in which the current system of subsidies and other government support keeps meat artificially cheap". ${ }^{32}$

Indeed, in the meantime, it has been done exactly the contrary: even political parties allegedly standing for reforms of the system have advocated for: further financing farmers; ${ }^{33}$ or for unstunned slaughter of non-human animals; ${ }^{34}$ furthermore, the European Court on the Human Rights has confirmed the prohibition of certain propaganda against the consumption of meat, ${ }^{35}$ completely disregarding any health or environmental concern.

Not only political parties and supreme courts, but also international institutions seem to be blamed.

"The World Health Organization has proposed new nomenclature for the various strains of influenza A (H5N1), the bird flu virus circulating in Eurasia and Africa. The strains would now be enumerated rather than named after their countries or regions of origin. ... The proposed changes represent an epidemiological approach that may threaten our ability to impute bird

32 Roberts, P., cit., 315-316.

33 Point 6 of the Manifesto of the Italian 5 Stars Movement for the 2014 campaign for the election of the European Parliament, at: https://formiche.net/files/2014/05/movimento-5-stelle-programma7punti.pdf (accessed October 20, 2020).

34 A "green" Belgian party, Ecolo, has printed and distributed flyers supporting the unstunning slaughter of non-human animals, during the 2019 election campaign. See "Elections 2019: polémique autour d'un tract Ecolo distribué dans un marché à Bruxelles”. May 15, 2019. Le Soir. https://www. lesoir.be/224399/article/2019-05-15/elections-2019-polemique-autour-dun-tract-ecolo-distribue-dansun-marche (accessed October 20, 2020). The flyer has then been withdrawn, but the position on unstunned slaughter remained substantially the same. See "Port du voile, abattage rituel... Ecolo ordonne le retrait d'un tract polémique sur la liberté de culte (photos)”. May 15, 2019, RTL Info. https:// www.rtl.be/info/belgique/politique/port-du-voile-abattage-rituel-ecolo-ordonne-le-retrait-d-un-tractpolemique-sur-la-liberte-de-culte-1124432.aspx (accessed October 20, 2020).

35 See Regaldo, F. 2013. "Freedom of Speech and Protection of «Profitable Livestock». Some Remarks on the Case «PETA Deutschland v. Germany» (European Court of Human Rights, November 8, 2012)", in Materiali per una storia della cultura giuridica (2), $445 \mathrm{ff}$. https://www. rivisteweb.it/doi/10.1436/74972 (accessed October 20, 2020). 
flu's causes, to implement appropriate interventions, and to name the names of those responsible for controlling local outbreaks. If a strain of bird flu appears to newly emerge out of a specific province or state of an affected country, that country is responsible for intervening in a way that the outbreak and any sequelae are controlled. Labeling a strain by its probable locale of origin reminds us which countries are responsible and where attention must be directed. Even if the strains subsequently spread, their geographic origins are integral to learning more about the virus's molecular and epidemiological characteristics, as well as preventing the emergence of similar strains. Cause and blame, then, appear to be the crux of the matter. The terminology WHO characterizes as 'stigmatizing' may be viewed instead as solely definitional, a part of pinpointing causality". ${ }^{36}$

Therefore, in spite of the fact that it is very important, for scientists, to know the causes (and so also the exact location) that gave origin to a virus, at WHO it has been held, on the contrary, that: "It's very important that naming of viruses is done in a way that doesn't stigmatize countries, that doesn't stigmatize regions and doesn't stigmatize individual people". ${ }^{37}$

"The awful irony, however, is that the next influenza pandemic will be the first for which scientists will be able to pinpoint a locality of origin, even, if sampling continues to improve, to the very farm of origin or by Global Positioning Systems coordinate". ${ }^{38}$

It seems that the prophetical words of Paul Roberts and Rob Wallace have now become reality, with the current Covid-19 pandemic, whose origin appears to be located in a so-called "Wet Market" of Wuhan, Hubei, China, although, for the sake of completeness, it must be noted that, at the time of writing, a biological lab provenience cannot be completely ruled out. ${ }^{39}$

Nevertheless, if such "Wet Market" origin is confirmed, it should be simplistic to exclusively blame the manager of Wuhan's market, the region of Hubei or the entire China for this catastrophe.

Rob Wallace posed this key question to himself very well in advance of the current pandemic and the answer he gave is the following:

36 Wallace, R. cit., 168-191.

37 Idem, 348.

38 Idem, 376.

39 See the investigation recently broadcasted by an Italian television channel: "Sars-CoV-2: identikit di un killer”. 2020. RAI 3, Presadiretta. https://www.raiplay.it/video/2020/09/PresaDiretta-Sars-CoV-2-identikit-di-un-killer-466d5ae5-4f7c-4357-b124-aba6bb0d2c82.html (accessed October 20, 2020), with interviews to several experts, including Nikolai Petrowsky, Jack Nurnberg and Matt Ridley, who are claiming that the origins of Sars-CoV-2-are still uncertain. 
"Should we blame China for repeatedly seeding outbreaks regionally and internationally? Or should we blame the United States, where the industrial model of vertically integrated poultry first originated, with thousands of birds packed in as so much food for flu? The answers are yes, yes, and yes". ${ }^{40}$

Although the first response of Rob Wallace looks suggestive, he then points out that there is rather a business sector who should be blamed and held responsible for pandemics:

\begin{abstract}
"If multinational agribusinesses can parlay the geography of production into huge profits, regardless of the outbreaks that may accrue, who pays the costs? The costs of factory farms are routinely externalized. As Peter Singer explains, the state has long been forced to pick up the tab for the problems these farms cause; among them, health problems for their workers, pollution released into the surrounding land, food poisoning, and damage to transportation infrastructure. A breach in a poultry lagoon, releasing tons of feces into a Cape Fear tributary, causing a massive fish kill, is left to local governments to clean up. With the specter of influenza the state is again prepared to pick up the bill so that factory farms can continue to operate without interruption, this time in the face of worldwide pandemics agribusiness helps cause in the first place. The economics are startling. The world's governments are prepared to subsidize agribusiness billions upon billions for damage control in the form of animal and human vaccines, Tamiflu, culling operations, and body bags". ${ }^{41}$
\end{abstract}

Furthermore, it seems that, amongst farmers, those who must be blamed more are the ones who are engaged in CAFOS: "Graham et al. found significantly greater odds for H5N1 outbreaks in Thailand 2004 in large-scale commercial poultry operations than in backyard flocks. The pattern is repeated across influenza serotypes. ... Even if these and other such strains first developed on smallholdings ..., industrial livestock appear ideal populations for supporting virulent pathogens. Growing genetic monocultures of domestic animals removes whatever immune firebreaks may be available to slow down transmission". ${ }^{42}$

It seems that the most urgent need is terminating intensive farming:

"Ending large livestock operations as we know them could make a great difference in Guangdong as elsewhere. Such politically protected operations appear to promote both pathogen virulence and transmission. Graham et al. review a number of proximate environmental pathways by which pathogens can spread across and out of large confined animal feedlot operations, including via animal waste handling and use in aquaculture, workers' occupational exposure, open transport of animals between farms and processing plants,

40 Wallace, R. cit., 385.

41 Idem, 712-717.

42 Idem, 847-852. 
contamination of shipping containers, non-livestock animals such as rats and flies, and tunnel ventilation systems that blow animal materials into the environment". ${ }^{43}$

"The industry has survived only by long externalizing the costs of disease, pollution, and labor violations. Governments and consumers the world over have had to pick up the check. It's high time those costs showed up instead on the industry's balance sheets or at the very least in addition". ${ }^{4}$

The latter observation induces me to a firm ascertainment: pandemics are strictly linked with the term "zoonotic": the production of tomatoes, of grapefruit or of spinaches do not present any risk of causing pandemics. It is true that industrial agriculture creates high risks of diseases also while producing, packing and selling fruits and vegetables, ${ }^{45}$ but no such disease can be compared with a pandemic. Poisoning of fruits and vegetables ends up with the unfortunate customer who eats them: it does not spread worldwide to persons who have no link whatsoever (save the one of belonging to the same species of Homo sapiens) with the practice which created the risk.

Therefore, no meat consumption nor non-human animal exploitation means no (or much lower) risk of pandemics.

And vice versa: as we have seen, it does not matter if it is a "Wet Market", populated by small farmers, or a CAFOS managed by a multinational: all breeding and slaughtering activities carry with them a certain degree of risk of zoonosis and triggering pandemics.

And, as we have also seen, it does not matter the country: from the chaotic China, to the very well organized Netherlands, from the poor Mexico to the rich British Columbia, any territory hosting breeding and slaughtering activities can be the source of a pandemic.

According to the principle, illustrated above, that "those who profit by exposing others to especially high risk will be using up more than their own share (of resources) if they are not held liable", responsible persons might be all those

43 Idem, 1214-1218.

44 Idem, 2103-2107.

45 E.g.: during the ' 80 s, around 1000 people died in Spain for a food poisoning due to tomatoes heavily contaminated by pesticides: See Woffinden, B. August 25, 2001. “Cover Up”, in The Guardian. https:// www.theguardian.com/education/2001/aug/25/research.highereducation (accessed October 20, 2020); in 1986, in Italy, 19 people died and others suffered tremendous injuries due to poisoning of wine with methanol: See: Miravalle, S. November 16, 2010. "Il silenzi(o) e le preghiere del 'cavaliere metanolo', in La Stampa. https://web.archive.org/web/20121127011443/http://www.lastampa.it/2010/11/16/blogs/ giro-di-vite/il-silenzi-e-le-preghiere-del-cavaliere-metanolo-t1rvxQhL6kNZmBOetnspIM/pagina.html (accessed October 20, 2020); in late October of 2006, E. coli 0157:H7 had been found in bags of fresh spinach that had killed three people and sickened some two hundred others: see Roberts, P., cit., prologue; and this list, unfortunately, can go on and on for pages. 
who make profit out of non-human animals, either directly (farmers) or indirectly (transporters, butchers, distributors, resellers, etc.), whenever a pandemic outbreak is specifically connected to their activity: actually, all of them make profit out of a dangerous activity, by externalizing the risks and costs of diseases potentially spreading out to the world at large.

In other words, assuming that the current pandemic originated from pangolins slaughtered and sold at Wuhan's Wet Market, ${ }^{46}$ responsible persons, according to the principle above, should be: pangolins' hunters, transporters, butchers, resellers, etc. Responsible should also be those who control and organize such dangerous trade, like, I suppose, Wuhan's Wet Market managers.

Certainly, sometimes it is relatively easy to identify the responsible persons: it is the case of outbreaks originated within a specific CAFOS.

In other cases, not only it is extremely complicated to retrace the chain of infection, but it is even more difficult to clearly identify one or more specific persons that with their reckless activity gave origin to the outbreak.

Therefore, e.g. assuming that the current pandemic originated in Wuhan's Wet Market (which is already difficult to establish with certainty, as we saw above), it could be virtually impossible to establish if the very first zoonotic episode that triggered the pandemic took place within the range of activity of, respectively: pangolins' hunters, transporters, butchers, resellers or others.

Only by applying the principle that "those who profit by exposing others to especially high risk will be using up more than their own share (of resources) if they are not held liable" all the above subjects could be held accountable.

Since contamination - and therefore zoonosis - can take place at any stage of the meat production process (see note No. ${ }^{43}$ ), all the persons involved in such meat production chain have the same duty of care.

Indeed, there are certain kind of pandemics ultimately caused by those who destroy natural habitats, expulsing the local wildlife, and increasing the opportunity of inter-species contacts with humans, including the transmission of viruses:

"Ebola illustrates this well. A 2017 study found that outbreaks of the virus, the source of which has been localized in various bat species, are more common in areas of West and Central Africa that have recently suffered deforestation. When we cut down their forests, we force the bats to perch on the trees in our gardens and on our farms. It is therefore easy to imagine what happens next: a human ingests bat saliva by biting into a fruit that is covered with it, or, while trying to hunt and kill this unwelcome visitor, is exposed to microbes who have found refuge

46 Maselli T. February 8, 2020. “Coronavirus: all'origine dell'epidemia il consumo di pangolino, specie a grave rischio estinzione”, in @greenMe. https://www.greenme.it/vivere/salute-ebenessere/coronavirus-pangolino/ (accessed October 20, 2020). 
in his tissues. This is how a multitude of viruses of which bats are carriers, but which remain harmless at home, manage to penetrate human populations". ${ }^{47}$

If it is clear the responsibility in destructing natural habitats, by certain industries (e.g. palm oil), the direct and indirect contributors to widespread deforestation and urbanization are too numerous for being precisely enumerated and identified.

As the world is witnessing in these days, what it is certain is that the management of non-human animals carries with it the same (if not higher) degree of risks of the management of nuclear energy.

Death toll of Covid-19 is certainly higher than those of the Chernobyl and the Fukushima nuclear disasters, while the catastrophic economic impact is unprecedented. Therefore, it goes without saying that the liability chain cannot end up with the manager of the Wet Market or of the one of the corporation concerned.

Since injuries caused by pandemics are of the highest degree, also the behavior of States and international organizations should be evaluated according to the most severe standards. Any local, national or international authority or organization who could have done something, but has done nothing, despite being aware of the risk, should be held accountable for the breach of the duty of care or, transposing such concept to the civil law tradition, for culpa in vigilando.

To a certain extent, some local lawyers have already explored this path: it is the case of the several class actions promoted in the USA ${ }^{48}$ and several civil lawsuits promoted in Italy, ${ }^{49}$ all against the People Republic of China for omitting to react promptly vis-à-vis Covid-19; others are considering to bring China, for the same reasons, before the International Court of Justice. ${ }^{50}$

47 Shah, S. March 17, 2020. “Contre les pandémies, l'écologie”, in Le Monde diplomatique (my translation). https://www.monde-diplomatique.fr/2020/03/SHAH/61547 (accessed October 20, 2020). See also: Brenna, L. March 1, 2020. “Coronavirus. Non dobbiamo aver paura degli animali, ma di ciò che stiamo facendo ai loro habitat”, in Lifegate. https://www.lifegate.it/persone/news/ coronavirus-fauna-selvatica-animali-domestici (accessed October 20, 2020); Diprose, K. and Neal M. April 11, 2020. "Jane Goodall says global disregard for nature brought on coronavirus pandemic", in ABC News. https://www.abc.net.au/news/2020-04-11/jane-goodall-says-disregard-for-nature-hasbrought-coronavirus/12142246 (accessed October 20, 2020).

48 See inter alia: Taylor, S. May 2020. "Lawsuit worth $\$ 6$ trillion seeks reparations from China for 'cover-up' of coronavirus pandemic”, in 60 Minutes. https://9now.nine.com.au/60-minutes/sixtrillion-dollar-lawsuit-china-reparations-for-coronavirus-global-pandemic-60-minutes/6e1daf78cf60-404b-bcae-f22282529b22 (accessed October 20, 2020).

49 Cit., note 11.

50 Taylor, S., cit, reporting the intention of an Australian politician. 
On this latter aspect, it is worth remembering that the OECD, already in 2010, published the: "Good Practices for Mitigating and Financing Catastrophic Risks", clearly stating that governments should promote the development of efficient strategies for fighting against negative economic effect of large-scale catastrophes. ${ }^{51}$

\section{Minimizing the Risks in the Near Future}

The injuries caused by a pandemic are catastrophic, the identification of the responsible person is often difficult and, in any case, it is always insolvent with reference to the huge damaged caused. As a matter of fact, this is a classical situation in which the traditional ex post structure of individual rights protection is purely illusive and completely unsatisfactory.

Focus should be directed to pandemic prevention, rather than to pandemic compensation.

Setting up of worldwide policies for responding to prevention needs is not a matter than can be thoroughly dealt with in this article.

However, from what it has been reported above, it appears quite clearly that meat and dairy production has the characteristics of (and should be treated as) a dangerous activity.

The current pandemic has shown that it is not naïve to draw a parallelism between meat and dairy production and nuclear energy production: both activities are extremely dangerous and, at a superficial look, they seem indispensable in the current society.

A more attentive examination, though, proves that none of these activities is indispensable and as sooner as they will be abandoned as better it will be for the society of the third millennium.

In fact, both nuclear power and meat and dairy products offer enormous amount of energy, respectively for the need of the society and for the diet of its individuals.

The first question one has to ask is: do the society/individuals need such enormous amount of energy?

With reference to electric energy, the answer is: yes, still, unfortunately. Progress have been made in reducing energy consumption, e.g. in the illumination sector, by replacing old incandescent lamps with newer low-energy consumption led lamps; international standards have been put in place, in order to reduce stand-by consumption of home devices; etc.

51 Monti, A., cit., 1397. 
However, demand of electric energy remains stratospheric and it will ever increase, with the progressive shift from petrol motor vehicles to electrical ones.

Notwithstanding the above, wiser States are planning to fully decommissioning the existing nuclear power plants in the next few years and to replace them with greener and high-tech forms of energy production, like e.g. offshore giant wind turbines. Risks relating to the management of nuclear power plants, in the long run, are simply unsustainable, even with a growing demand of energy.

Let us go back to the same question, with reference to the energy obtained, in the form of calories, through eating highly energetic food: do the individuals need such enormous amount of calories?

Contrary to the response given for electrical energy, the one for calories intake is a clear and unequivocal "no" and this at a worldwide level.

In Western societies, a high calories diet is strictly linked with obesity and lethal diseases. ${ }^{52}$

On the other hand, one could object that, in developing Countries, exposed to the risk of famine, calories are indeed strongly needed. The objection is probably grounded, but the best way of obtaining calories is certainly not through promoting the meat and dairy consumption.

Meat consumption is the most inefficient way to nourish people: an Australian study has shown that, in Australia: farming is responsible for $11 \%$ of all $\mathrm{CO}_{2}$ emissions; for producing $200 \mathrm{~g}$ of beef, $25.000 \mathrm{~L}$ of water are requested; and soil occupation, for producing $1 \mathrm{~kg}$ of meat, is 15 times higher than the one for producing $1 \mathrm{~kg}$ of cereals and 70 times higher than the one for producing $1 \mathrm{~kg}$ of vegetables. ${ }^{53}$

In other words, promoting meat and dairy consumption in developing Countries shall produce environmental devastation and shall not solve the famine problem.

On the other hand, a green revolution is on his way: high-tech solutions for efficiently producing fruit and vegetables are now available also to small farmers, preserving both the environment and the traditional way of living.

52 “(...) America has a weight problem. In fact, two out of three adult Americans are overweight and one-third of the adult population is obese. Not only are these numbers high, but the rate at which they have been rising is ominous" and "There is nothing better the government could do that would prevent more pain and suffering in this country than telling Americans unequivocally to eat less animal products (...) " [Campbell, T. C. and Campbell, T. M. 2006. The China Studies. Dallas: BenBella Books, respectively at 135 and 305].

53 Data are reported in Angelini, G., eds. (2012). "I costi reali del ciclo di produzione della carne Rapporto LAV”, in Impronte (3): 55. 
Finally, meat and dairy products are replaced, more and more, by vegetarian ${ }^{54}$ or lab ${ }^{55}$ products, highly resembling in taste to the original products.

In sum, CAFOS and Wet Markets are no longer needed in the society of the third millennium, even much less than nuclear power plants are needed.

Thinking that future pandemics can be prevented by introducing new food regulations in CAFOS and Wet Markets is not only a rear-guard action, but also a mere illusion.

A growing demand of (original and not lab) meat and dairy products by a growing population of billions of people requires the setting up and expansion of CAFOS or, as otherwise defined, of "Big Farms who Make Big Flu".

CAFOS contain even one hundred thousand animals in cages, in horrendous conditions, immuno-depressed and in constant need of drugs: the ideal environment for creating pandemics.

It is not by reducing the number of animals from 100,000 to 90,000 or by enlarging the cages from 2 to $2.5 \mathrm{~m}^{2}$, that the risk of pandemics shall be reduced.

At the same time, it is not by reducing the number of species that can be slaughtered in front of customers at Wet Markets (e.g. dogs, cats and now baths and pangolins, not; beavers and porcupines, yes) that the risk of pandemics shall be reduced.

CAFOS and Wet Markets must be shut down.

In order to achieve this goal, action must be taken to reduce the demand of meat and dairy products, as suggested in the paper. This, in the opinion of the author, is the only specific and feasible solution. It is also the quickest to implement.

Indeed, only a reduction of the demand of meat and dairy products would render CAFOS and Wet Markets less profitable and would hopefully lead to their shut down.

Furthermore, advocating for a reduction in the demand of meat and dairy product is a fully legitimate claim: for many years, meat and dairy production has externalized huge costs to the society (in terms of pollution, deforestation and health concerns) and the pandemic's bill left to be paid to every one of us appears to be just the most recent one.

This dangerous activity, no longer compatible with a world inhabited by more than seven billion people, cannot be reformed, but must end.

54 There are now available on the market vegetarian products reproducing the taste of even the most specific traditional and local productions.

55 Another revolution is on his way. See: Owen Schaefer, G. September 14, 2018. "Lab-Grown Meat - Beef for dinner-without killing animals or the environment”, in Scientific American: https:// www.scientificamerican.com/article/lab-grown-meat/ (accessed October 21, 2020). 
Since no meat (and no derivative) product consumption means no (or much lower risk) of pandemics, which are the tools for trying to achieve this target as soon as possible?

The challenge is a colossal one. First of all, in economic terms: in the USA only, agribusiness is an industry worth USD 125 billion, controlled by few large corporations, whose interests are inextricably connected to those of the government, rendering difficult to find out the boundary between profit motivation and public policy. ${ }^{56}$

Such a powerful apparatus exploits what Melanie Joy defines as the three "N" of the mythology of meat. To the largest public, eating meat appears to be: "Normal"; "Natural" and "Necessary". It goes without saying that all these three "N" are deeply fallacious: "These three 'N' have been evoked to justify all forms of exploitation, from the slavery in Africa to the Nazi Holocaust. While an ideology is at the pinnacle of its popularity, such myths are rarely put into question. However, when the system eventually collapses the three 'N' are recognized as absurd". 57

Sometimes, such exploitation may be reinforced through leveraging on religious beliefs: e.g. Confucianism supports a distinction between the "enlightened" men and others, including other men and beasts. ${ }^{58}$ Perhaps, it can be explained in this way the complete absence of compassion towards "beasts", all species of "beasts", in Chinese Wet Markets, when non-human animals are slaughtered in front of the customers.

From this point of view, the principles of the Mediterranean monotheisms are not so different: only human animals look like God and non-human animals can be freely exploited, reduced to slavery and killed by the former. ${ }^{59}$

The only difference is that, in current Western societies, few species of nonhuman animals (mainly dogs and cats) have (incoherently) obtained some protection. All the other species are treated exactly like in China, although, hypocritically, not openly, but between closed doors: "it is estimated in more than 500 million the number of animals, predestined to become food, who die before reaching slaughterhouses, incidents included in the production costs.

56 Joy, M., cit., 1421-1425.

57 Idem, 1551, my translation. For a complete and punctual demonstration of the fallacious system of the three "N", see 1688-1804.

58 Cyrulnik, B. eds (1998). Elisseeff, D., "Le rapport homme/animal: quelques vérités premières à la source des croyances chinoises”, in Si les lions pouvaient parler, essais sur la condition animale. Paris: Gallimard, 1484.

59 “Then God said, 'Let us make mankind in our image, in our likeness, so that they may rule over the fish in the sea and the birds in the sky, over the livestock and all the wild animals, and over all the creatures that move along the ground', Genesis, 1:26. 
Such cost-reduction measures render the modern meat production system one of the cruellest practices of human history". 60

Western-made intensive farming, relying on US and EU laws for allowing: mutilation of piglets and chickens without narcosis, forced separation of newlyborne calves from their mothers, restraint cages for nursing sows, killing through electrocution of foxes in fur farms, the shredding of millions of live chicks and other unspeakable practices, ${ }^{61}$ is therefore much more insidious than Asian Wet Markets.

There is nothing rational and efficient in the Western meat and dairy production models and eating habits versus the irrationality and inefficiency of the Asian way:

"Cultural patterns draw the line not only between legal and illegal products, but also between acceptable and inacceptable ways of consuming". ${ }^{62}$

Indeed, while in Chinese Wet Markets, brutality on the weaker is open air and can be clearly identified, in Western consumer habits, brutality on the weaker is inherently part of the systems and everything is done to keep it in the shade. In both cases, neither the Chinese nor the Western cultures leave any room for compassion and anti-speciesism.

Anyway, non-human animal farming, for the pandemic risks it exposes humankind, should be treated, at least, as the most dangerous industries, like tobacco.

Carnism is a cultural pattern and cannot be changed (at least, in the short term) through enacting direct restrictions on the demand, as the disastrous experience of alcohol trade laws in the US showed us. ${ }^{63}$

Change can take place only by displaying more intelligent measures, aiming at reducing the financial profitability of the industry, while raising consumer awareness of the hidden costs related thereto.

Therefore, in my view, the following immediate measures should be taken:

60 Joy, M. cit., 617, my translation.

61 Idem, 2993-2998.

62 Scaffardi, L. and Zeno-Zencovich, V. eds (2020). Rossi G., "The Long Wave of Prohibition: Alcohol Trade Laws in the US, in Cibo e diritto - Una prospettiva comparata“ in Atti del XXV Colloquio biennale Associazione italiana di diritto comparato - Parma 23-25 maggio 2019. Rome: RomaTre-Press, (II), 732. The Author points out that, with reference to alcohol control regulation, law is far from being driven by efficiency considerations: Indeed, the influence of cultural patterns extends "not only to controls on quantities, or age-limits, or features of each substance (like alcoholic grade), but also to places of consumption (private or public, saloons or high-class lounge bars, restaurant or taverns) social features of people drinking together (bourgeoisie or working class, a restricted group of selected guests or a disordered crowd), and so on" (Idem).

63 Idem. 
1) Revoking all financing to non-human animal farming by public authorities. Unfortunately, recent proposals to cut financing to non-human-farming have been rejected by the European Parliament; ${ }^{64}$

2) Banning all advertising of meat and dairy products.

Besides creating the risk of pandemics, it has been established that processed meat consumption is linked with cancer. ${ }^{65}$ There are also studies linking the consumption of dairy products inter alia with prostate cancer ${ }^{66}$ and of animal fat intake (including from milk and dairy products) to breast cancer. ${ }^{67}$ Last but not least, non-human animal farming ranks amongst the highest factors of worldwide pollution. ${ }^{68}$

Nevertheless, advertising of meat and dairy products is widespread, broadcasted on TV at all times and even using children as testimonials.

Advertising of meat and dairy products, due to all the risks as shown above, should be treated, at least, like the one of tobacco products: not only a ban should be enforced, but an obligation to display images of the devastating consequences on public health and environment on all packages should be rapidly introduced.

3) Promoting campaigns against consumption of meat and dairy products.

Ironically, while commercials for meat and dairy products are so massive, freedom of speech of animal rights campaigners, aiming at raising public concern over meat consumption has been seriously impaired, both at national and EU level.

E.g. in Italy, advertising posters reproducing a doll, cut in pieces and packed in a tray, jointly with the following sentence: «Who are you going to eat today? Animals are not things. When you eat them or exploit them, you eat somebody. Not something. Go vegan» (my translation) have been prohibited by the Panel on Advertising; ${ }^{69}$ in Europe, advertising posters suggesting a comparison

64 Gaita, L. April 2, 2019. "Industria carne, Parlamento Ue dice no al taglio dei finanziamenti. E la Lombardia 'protegge' glI allevamenti intensivi”, in Il Fatto Quotidiano. https://www. ilfattoquotidiano.it/2019/04/02/industria-carne-parlamento-ue-dice-no-al-taglio-dei-finanziamentie-la-lombardia-protegge-gli-allevamenti-intensivi/5081473/ (accessed October 21, 2020).

65 Simon, S. October 26, 2015. "World Health Organization Says Processed Meat Causes Cancer”, in American Cancer Society. https://www.cancer.org/latest-news/world-health-organizationsays-processed-meat-causes-cancer.html (accessed October 21, 2020).

66 Campbell, T. C. and Campbell, T. M., cit., 3 and 180.

67 Idem, 85.

68 Angelini, G., cit.

69 Giurì dell'Autodisciplina Pubblicitaria, decision No. 32 of 2013. 
between non-human animal farming and the Holocaust have been prohibited by the ECHR. ${ }^{70}$

With reference to EU intervention, it would look more than reasonable to divert the very same amount of public money, now invested in promoting farming, towards public interest campaigns and initiatives for abolishing and replacing meat and dairy consumption.

4) Setting up an international organization aiming to put pressure on Countries with the highest level of intensive farming and/or livestock markets. Such an organization should be: (i) able to draft and update an accurate map of risks of pandemics worldwide; (ii) granted powers and resources to force and compensate farming decommissioning and (iii) capable of restraining access to the international trade, for Countries unwilling to materially diminish their contribution to the risk of pandemics.

Certainly, in setting up such organization, lessons should be drawn from the failure of the United Nations Framework Convention on Climate Change of 1992. ${ }^{71}$ Humankind cannot waste another 30 years for trying to display effective global means for tackling the problem. With the current situation, pandemics are imminent. After Covid-19 pandemic, others and more dangerous shall come forward, if nothing is done in the meantime.

\section{Eliminating the Risks in a Better (and the Only Possible) World}

What is the likelihood that the suggested measures above shall be adopted?

The response depends upon the capability of the political system to escape from the influence of lobbies, which, at the time being, looks nearly impossible.

Indeed, so far, pressure groups connected to agricultural or pharmaceutical biotechnology or to the military industry have clearly defined the political agenda to all governments worldwide.

Bearing in mind that the demand for intensive farming products is on the rise everywhere - including within developing Countries - it is no secret that it will be very hard to put the suggested measure into practice.

Furthermore, the mainstream, in which politics and lobbies operate, is also widely shared and supported by the people: in order to stimulate consumptions,

70 Case of Peta Deutschland v. Germany, decision of the Court (V Chamber), of 8 November 2012. Further elements can be found in Regaldo, F., cit.

71 So far, an effective international law agreement in the interest of survival has been just a “wishful thinking”. See: Mattei, U. and Quarta, A., cit. Introduction. 
the industry exploits and leverages the cultural patterns, as shown by the three " $\mathrm{N}$ " of the mythology of meat, discussed above.

If, as it is the case nowadays, a certain product is strongly demanded on the market, it is extremely difficult for governments to hinder consumers' choices, which, under the pressure operated by advertising, are considered to be "normal". Finally, one has to consider how difficult it is, for governments, to face the pressure arising out of a very material number of job losses within the meat production industry.

Unfortunately, in nowadays society, political powers, as well as corporations, ${ }^{72}$ are characterized by short-termism. Governments are not interested in long-term policies and are heavily conditioned by the tribal interests shaking the political parties supporting them. Therefore, they are not capable of performing their task of directing economic and social processes independently from the various egoistical interests and they have no vision of the future of humankind.

E.g. apparently, it seems that some progress has been made within the area of environmental protection, including the issue of deforestation, pollution and rise of $\mathrm{CO}_{2}$ emission. Indeed, at a first sight, it seems that governments, forced by a scared public opinion, by young activists, by a growing number of scientist and climatologists as well by the evidence of more frequent and devastating natural events, have set the problem in the political agenda, under the heading of "green economy”. In such a way, jointly with the business community, an astonishing operation of "greenwashing" has taken place: nearly all industries are now trying to use, in a way or another, the prefix "eco" and the word "sustainability" for describing their own activities.

Nevertheless, the main problem has not been tackled yet. The meat production chain is the main responsible of environmental deterioration. It is the main source of: deforestation in the last regions characterized by biodiversity; waste of proteins (equal to the 9/10) and therefore world's famine; $\mathrm{CO}_{2}$ production; foolish use of resources; ${ }^{73}$ etc.

No greenwashing shall be sufficient without addressing the meat production problem and pandemics risks shall only be a part of this larger problem.

Resistance to change is also due to difficulties in depriving the enormous army of meat production workers of their jobs. Abandoning carnism shall first of all lead

72 Charkham, J. 1989. "Corporate governance and the market for companies: aspects of the shareholders' role”, in Bank of England Discussion Paper. London: Bank of England, 12-13; Davies, P. L. 1997. Gower's Principles of Modern Company Law, 6th ed. London: Sweet \& Maxwell, 816; Mitchell, A. and Sikka, P. 1996. “Corporate Governance Matters”, in Discussion Paper. London: The Fabian Society (24); Parkinson, J.E. 1993. Corporate Power and Responsibility. Issues in the Theory of Company Law. Oxford: Clarendon Press, $146 \mathrm{ff}$.

73 See note ${ }^{53}$ above. 
to a material rise in unemployment. This is the key aspect and namely the inner inefficiency of the system: the need to sustain billion of working hours for activities characterized by tremendous negative externalities, with negative repercussions even on the same workforce benefiting from the corresponding salary.

The meat production problem shows the profound inaptitude of the current political, economic and cultural institutions to secure the most authentic human needs, more and more urgently needed by the people and more and more radically denied by capitalism.

Perhaps, the current pandemic has given to humankind the last chance to have a rest from the "rat race" and radically change the economic, political and cultural model, if it wants to survive.

Change is therefore not an option, but rather appears as an urgent need:

"The ecological crisis, first and foremost, challenges the very foundational ideology of capitalism and modernity, the possibility of infinite growth on a final planet”. ${ }^{74}$

The above, combined with the new strategies of extraction and accumulation, experimented by capitalism through the Internet, and the dramatic concentration of power in private hands, has produced an unprecedented level of frustration and appeasement. $^{75}$

The current times are characterized by: confusion in the governance of world policies; degradation of the quality of politicians, at the global level; widespread aversion towards political institutions; propagation of local conflicts; recurrent and endemic economic crises; environmental catastrophes; and humanitarian crises, including pandemics.

All the above can be translated into a simple assertion: the increase in the suffering of people.

As GDP growth is lowering down, the aggression of non-renewable stocks of nature is rising up to a non-sustainable level.

Human history, as we know it, is characterized by violence: towards the weaker non-human animals; towards other humans; and towards the nature itself.

Capitalism is the ultimate form of this violent society, certainly different from its predecessors, but only for the higher scale of destruction it can produce.

However, the origin of the problem dates back of many millenniums, has probably come out in the deep Neolithic era, during the earlier herding society, ${ }^{76}$ and is related to both:

74 Mattei, U. and Quarta, A., cit., Preface.

75 Idem.

76 Sottofattori, A. 2020. Zoécomunismo, 255-256. http://www.criticadelleteologieeconomiche.net (accessed October 21, 2020). 
1) The concept of private property: under the traditional free market economy, the land has been considered as res nullius, capable of being occupied, exploited on an exclusive basis and traded. The very origin of this idea is fallacious. Land is not res nullius; it is res communes omnium ${ }^{77}$. Capitalism has only leveraged this intrinsically wrong principle;

2) The dominium by someone on others: slavery starts with the organized exploitation of non-human animals and extends to the dominium also on human animals, made throughout history by one or another of the so-called "elites". Also on this point, capitalism has only produced a leveraged effect, if it is true that the richest $1 \%$ of adults alone owned $40 \%$ of global assets in the year 2000 , and that the richest $10 \%$ of adults accounted for $85 \%$ of the world total. ${ }^{78}$

At the same time, humankind continues to believe in anthropocentrism, the stubborn belief of humans to be entities ontologically separated from the rest of nature.

The very essence of this global economic system, its profitability, is necessarily obtained at the cost of huge negative externalities, that can also take the resemblance of waste:

- Monetary waste, in the form of toxic, unrepayable bonds and loans;

- Material waste, polluting air, land and see; and now also

- Biological waste, in the form of lethal viruses.

Nowadays, humankind consumes 39\% more resources than it should be possible, in order not to exhaust the planet. The acceleration of this aggression to natural stocks is dramatic: if in 1970, the ecological footprint corresponded to the entire bio capacity of planet Earth, exhausting the entire flows of output, 48 years later, the so-called "overshoot day" (the day in which the flows of resources produced by the planet is exhausted) has shifted from December 31st to August 2nd. ${ }^{79}$

Therefore, there is no doubt that the current world order (or rather, disorder) not only does no longer grant a prosperous life for humankind, but is going to create catastrophic effects, posing the foundations for humankind disappearance.

We have seen that meat production and pandemics are closely linked with capitalism and the direct or indirect negative externalities it creates. Survival of the species is therefore probably subject to the departure of capitalism.

77 Idem, 28-29.

78 Davies, J. B., Sandstrom, S., Shorrocks, A. and Wolff, E. N. 2007. The World Distribution of Household Wealth. UC Santa Cruz, 7. https://escholarship.org/uc/item/3jv048hx (accessed October 21, 2020).

79 Sottofattori, A., cit., 226. 
What are the proposals for the reconstruction of the society on non-violent and more efficient basis?

Some authors ${ }^{80}$ claim that a new world order should be based on the following principles:

- The elimination of capitalism and rejection of market-based theories;

- The prevention of alternative practices, which remain anthropocentric and aimed at economic growth, although purportedly pursuing anti-capitalism;

- The establishment of an international governance, based on pre-defined policies aimed at reducing the destruction of natural resources, while providing to an allocation of the same, according to everyone's needs.

Others, ${ }^{81}$ although maintaining similar principles, emphasize the role of cybernetic technology automation in the natural resources management, in what has been called a: "resource-based economy", ${ }^{82}$ in which it is portrayed the inefficiency of private property versus the resource sharing.

Although the above theories are depicted as utopian by the mainstream, ${ }^{83}$ the harsh reality of nowadays, with billions of people affected by the pandemic and with worldwide economy on the edge of a catastrophe, is that the only utopia is continuing to blindly rely on capitalism and free market for solving the problems of our species.

80 Idem, presentation of the book, slide 15.

81 Joseph, P. 2011. Zeitgeist: Moving Forward. (Interview to Fresco, J.). https://www.youtube. com/watch?v=4Z9WVZddH9w (accessed October 21, 2020).

82 Idem, Interview to Fresco, J.

83 Mattei, U. and Quarta, A., cit., Preface. 